\title{
O STF e o controle de constitucionalidade: deliberação, diálogo e razão pública*
}

Virgílio Afonso da Silva**

\section{Introdução}

Em fevereiro de 1803 foi proferida aquela que, muito provavelmente, é a decisão judicial mais citada dos últimos 200 anos: a sentença no caso Marbury v. Madison, que inaugurou o chamado controle judicial de constitucionalidade das leis. ${ }^{1}$ Como sabido, sua importância não está na matéria objeto do litígio - a nomeação de William Marbury como juiz de paz no distrito de Columbia, Estados Unidos. Sua importância, para o direito constitucional do mundo inteiro, reside no fato de que, pela primeira vez, o Judiciário declarou-se competente para analisar a constitucionalidade de leis ou de atos dos poderes políticos (Legislativo e Executivo).

A escolha do tema - controle de constitucionalidade - tem duas motivações principais. A primeira é intrínseca ao concurso no qual este trabalho originalmente

\footnotetext{
* Este artigo é a versão escrita da prova oral de erudição, realizada em 15 de setembro de 2006, como parte do concurso para o cargo de professor titular de direito constitucional na Faculdade de Direito da Universidade de São Paulo. Ele deve ser compreendido, portanto, dentro dos limites de tempo e de possibilidades de aprofundamento que uma prova como essa impõe. A bibliografia citada também reflete o debate na época da realização do concurso. Contudo, devido ao lapso de tempo entre sustentação oral deste trabalho e sua publicação, em alguns momentos específicos pareceu-me necessário fazer algumas referências a trabalhos publicados depois de setembro de 2006. Sempre que isso ocorrer, essas referências estarão indicadas por um " ". Agradeço a Conrado H. Mendes e a Guilherme Leite Gonçalves a atenta leitura que fizeram da última versão deste texto e os importantes comentários sobre algumas de minhas ideias. [N. do R.: todo o texto foi ainda revisto conforme as novas regras ortográficas da língua portuguesa, de 1을 je janeiro de 2009.]

** Professor titular de direito constitucional da Faculdade de Direito da Universidade de São Paulo.

${ }^{1}$ Cf. Marbury v. Madison, 5 U.S. 137 (1803).
} 
se inseria: as ideias defendidas na tese por mim apresentada no concurso têm como locus principal de aplicação o controle judicial de constitucionalidade. ${ }^{2}$ A segunda razão é mais ampla: se tratado a partir de um enfoque adequado, o tema "controle de constitucionalidade" pode ser um catalisador de diversos temas centrais não só do direito constitucional contemporâneo - como a interpretação constitucional, a separação de poderes, a democracia, a organização do Judiciário, os direitos fundamentais e o federalismo - mas também da ciência política e da filosofia.

Tão importante quanto justificar a escolha do tema é fundamentar o enfoque adotado. Nesse ponto, também são necessários dois esclarecimentos. O primeiro deles também é intrínseco ao concurso no âmbito do qual este texto foi originalmente apresentado. Muitas vezes, as provas de erudição nos concursos para professor titular são compreendidas como provas de conhecimentos históricos. $\mathrm{O}$ tema escolhido - controle de constitucionalidade - não permite esse enfoque, porque é fenômeno contemporâneo. Além disso, um enfoque baseado em uma narrativa histórica pareceu-me reducionista.

Em segundo lugar, pretendo também evitar uma abordagem exclusivamente processual. No âmbito jurídico, o debate sobre controle de constitucionalidade fica, muitas vezes, limitado a discussões sobre ações processuais e efeitos de decisões judiciais, e as únicas conclusões possíveis acabam se restringindo à escolha desse ou daquele modelo, à proposição dessa ou daquela ação, à discussão sobre se deveríamos ou não ter um controle concentrado e um tribunal constitucional ou, ainda, à definição dos efeitos das decisões judiciais de inconstitucionalidade (no jargão jurídico, efeitos ex tunc ou ex nunc). Parece-me ser o momento de ir além desse enfoque. Por isso, também não pretendo adotá-lo aqui.

Para procurar escapar das perspectivas descartadas supra, este trabalho está estruturado da seguinte forma. Em primeiro lugar, pretendo analisar o surgimento do controle de constitucionalidade (tópico 1). Mas o foco dessa análise, insisto, não é uma narrativa histórica. O que pretendo é examinar a forma pela qual o controle de constitucionalidade foi fundamentado quando do surgimento dos dois principais modelos de jurisdição constitucional, o modelo norte-americano e o modelo austríaco. Intimamente associada à fundamentação do controle está a indagação acerca da própria necessidade de um guardião da Constituição. A essa indagação será dedicado o tópico 2. O tópico seguinte ocupa-se dos principais modelos de controle de constitucionalidade. Mais uma vez, a intenção é ir além das análises tradicionais, que costumam se limitar à comparação de modelos com base em dois binômios básicos: controle prévio versus controle posterior e controle difuso versus controle concentrado. O que se pretenderá demonstrar é que, embora boa parte

\footnotetext{
${ }^{2}$ Silva, 2009.
} 
da literatura jurídica em língua portuguesa pretenda explicar as diversas formas de controle de constitucionalidade a partir desses binômios, ${ }^{3}$ em muitos casos eles não são suficientes para marcar as diferenças que existem entre os diversos arranjos institucionais nesse âmbito. Como se tentará demonstrar, pelo menos tão importante quanto essas dicotomias, é a análise sobre como se dá a deliberação nos tribunais encarregados de controlar a constitucionalidade das leis. A partir dessa mudança de foco, ficará claro que o modelo brasileiro, embora cada vez mais institucionalmente concentrado no Supremo Tribunal Federal, ainda continua muito distante dos modelos europeus de tribunais constitucionais. E essa distância, como se perceberá, não está relacionada à subsistência do controle difuso no Brasil, mas sobretudo à forma de deliberação e decisão adotada no STF. Esse debate levará ao tema do tópico subsequente (tópico 4), que pretende reconstruir a discussão sobre o controle de constitucionalidade a partir de premissas diversas das meramente processuais ou formais, analisadas nos tópicos iniciais do trabalho. Essas premissas estão associadas a alguns conceitos-chave: diálogo constitucional, pensamento institucional, modelos alternativos de jurisdição constitucional, deliberação e razão pública. O tópico seguinte pretende introduzir o modelo brasileiro na discussão, para tentar, entre outras coisas, demonstrar que é possível, também no Brasil, ir além dos aspectos processuais e formais do problema. Isso levará à conclusão (tópico 6), que se dedica à dicotomia entre a importação e o aperfeiçoamento de um modelo de jurisdição constitucional.

\section{Surgimento e fundamentação do controle de constitucionalidade: as "lógicas" de Marshall e de Kelsen}

O controle de constitucionalidade, tal como o conhecemos hoje, é uma ideia com dupla paternidade. Ao lado de John Marshall, presidente da Suprema Corte norte-americana à época da mencionada decisão Marbury v. Madison, e principal autor intelectual da argumentação que levou à criação do controle judicial de constitucionalidade nos Estados Unidos, está, sem dúvida nenhuma, o nome de

\footnotetext{
${ }^{3}$ Cf., por exemplo, Canotilho, 1998:790 e segs.; Miranda, 1983:310 e segs.; Silva, 2006:49 e segs.; Barroso, 2006:41 e segs.; Ferreira Filho, 2006:36 e segs.; Tavares, 1998:12 e segs. Algumas dessas análises fazem menção, entre outras, às contraposições entre controle concreto e controle abstrato, e entre controle por via incidental e controle por via de ação. Embora não sejam sinônimas, essas duas contraposições serão assimiladas neste trabalho à contraposição entre controle difuso e controle concentrado, já que elas, sobretudo nos casos em que mais importam, costumam coincidir.
} 
Hans Kelsen, autor de um dos anteprojetos da Constituição austríaca de $1920^{4}$ e, posteriormente, juiz do Tribunal Constitucional da Áustria. Se, com Marshall, é colocada em prática a ideia de controle de constitucionalidade, o projeto de Kelsen dá vida à ideia de um tribunal especificamente encarregado desse controle e monopolizador das decisões de inconstitucionalidade. ${ }^{5}$

Não se pretende, com isso, afirmar que a ideia de controle de constitucionalidade, em si, surge com Marshall, ou que Kelsen tenha sido o primeiro a pensar em uma instituição nos moldes dos tribunais constitucionais contemporâneos. No caso norte-americano, no Federalista 78 [Hamilton] já se defendia a necessidade de um controle semelhante. ${ }^{6}$ No caso do controle de tipo europeu, a Constituição austríaca nem mesmo foi a primeira a prevê-lo, tendo sido antecipada em alguns meses pela Constituição da Tchecoslováquia. O próprio Kelsen sempre deixou claras as suas fontes inspiradoras, sobretudo uma obra pouco divulgada de Georg Jellinek, sugestivamente intitulada Um tribunal constitucional para a Áustria, publicada em 1885. ${ }^{7}$ Ainda no plano das ideias, um embrião daquilo que mais tarde tomou a forma de tribunal constitucional pode ser encontrado na tentativa de Sieyès de implantação de um Jury Constitutionnaire, rejeitada pela Assembleia Constituinte de 1795. ${ }^{8}$ A despeito desses - e de quaisquer outros - antecedentes, foi a obra de Marshall e Kelsen que perdurou no tempo.

Como salientado no início deste trabalho, a menção ao surgimento do controle de constitucionalidade e, por decorrência, a menção a Marshall e Kelsen, não desempenham aqui a simples função de relato histórico. O que importa na obra de ambos não é a curiosidade histórica, mas a forma como eles fundamentaram a necessidade de um controle judicial de constitucionalidade. E isso pelo fato de que, até hoje, muitos juristas continuam a fundamentar o controle de constitucio-

\footnotetext{
${ }^{4}$ Sobre o papel de Kelsen na elaboração da Constituição austríaca de 1920, cf. Paulson, 2001:385 e segs.

Cf. Bongiovanni, 2007:293 e segs. Como observa Paulson (p. 389), pelo menos no que diz respeito ao Tribunal Constitucional, as sugestões de Kelsen foram aceitas "sem exceção" pela subcomissão responsável pelo assunto.

${ }^{5}$ No caso de Marshall, a referência suficiente é a já citada decisão no caso Marbury v. Madison (5 U.S. 137 [1803]). No caso de Kelsen, as referências são mais variadas. Alguns trabalhos abordam o problema da inconstitucionalidade, sobretudo do ponto de vista da teoria do direito (cf. Kelsen, 1960:275 e segs.); outros preocupam-se mais com o problema institucional do controle de constitucionalidade (cf. Kelsen, 1929:31-88; há ainda uma versão similar francesa publicada um ano antes: Kelsen, 1928:197-257). Cf., ainda, Kelsen, 1949:155 e segs.

${ }^{6}$ Cf. Hamilton, Madison e Jay, (1952): “É muito mais racional supor que os tribunais tenham sido concebidos para ser um corpo intermediário entre o povo e os legisladores, com o objetivo de, entre outras coisas, manter os últimos dentro dos limites conferidos à sua autoridade. (...) Compete a eles [os juízes] determinar o sentido [da Constituição], bem como o sentido de qualquer ato particular oriundo do corpo legislativo. Se houver uma variação inconciliável entre ambos, deve-se dar preferência, obviamente, àquele que tem obrigação e validade superiores; em outras palavras, a Constituição deve ter preferência sobre as leis e a intenção do povo, sobre a intenção de seus agentes".

${ }^{7}$ Cf. Jellinek, 1885. Ver, sobre a questão, Noll, 2000:261 e segs. e Eisenmann, 1928:157 e segs.

${ }^{8}$ Cf. Sieyès, 1795 reproduzido em Sieyès, 2007 . Sobre o assunto, ver, também, Burdeau, 1969:408-410 e Bastid, 1939:429 e segs.
} 
nalidade com argumentos semelhantes aos usados por Marshall e Kelsen. Nesse âmbito, costuma-se falar da "lógica de Marshall” e da "lógica de Kelsen". Mas será que há, no âmbito do controle judicial de constitucionalidade, espaço para lógica? Há como se falar, de fato, em "lógica de Marshall" ou "lógica de Kelsen"? Seria a fundamentação do controle judicial uma simples questão de lógica?

Embora não seja possível realizar uma análise mais detida da questão, é possível resumi-la em alguns pontos centrais. ${ }^{9}$ Para tanto, reproduzo a síntese de Nino (1996:190) sobre a fundamentação do controle judicial de constitucionalidade feita por Marshall: ${ }^{10}$

Premissa 1: O dever do Judiciário é aplicar a lei.

Premissa 2: Se há duas leis contraditórias, a aplicação de uma delas exclui a aplicação da outra.

Premissa 3: A Constituição é a lei suprema e define quais outras normas são jurídicas.

Premissa 4: A supremacia da Constituição implica que, nos casos de conflito entre a constituição e uma lei ordinária, esta última deixa de ser válida.

Premissa 5: Se a premissa 4 não fosse verdadeira, o legislador ordinário poderia modificar a Constituição por meio de lei ordinária, o que significaria que a Constituição deixaria de servir como limitadora da ação do legislador ordinário.

Premissa 6: O legislador ordinário é limitado pela Constituição.

Premissa 7: Se uma norma não é válida, ela não tem força vinculante.

Conclusão: se uma lei ordinária é contrária à Constituição, ela não vincula o Poder Judiciário. ${ }^{11}$

Embora esse raciocínio "lógico" costume ser aceito, ou seja, ainda que seja comum aceitar que da supremacia da Constituição decorre necessariamente o controle judicial de constitucionalidade, ${ }^{12}$ contemporaneamente há, cada vez mais,

\footnotetext{
${ }^{9}$ Para uma análise mais aprofundada, ver Nino, 1996:187 e segs. e Troper, 2003:99 e segs. O que se segue no texto baseia-se, em grande medida, na análise de Nino.

${ }^{10}$ Aqui, também por razões de espaço, faz-se menção indistintamente a Marshall e Kelsen, embora as fundamentações de ambos para o controle judicial de constitucionalidade não sejam idênticas. Para mais detalhes sobre as diferenças entre ambos, Nino, 1996:189 e segs. e Troper, 2003:105 e segs.

${ }^{11} \mathrm{O}$ trecho do voto de Marshall, no qual o esquema feito por Nino está baseado, é aquele presente sobretudo nas páginas 177 e 178 da decisão Marbury v. Madison.

${ }_{12}$ Nesse sentido, por exemplo, Nunes, 1943:581; Bandeira de Mello, 1934:75 e segs.; e Barbosa, 1933:129.
} 
autores que colocam isso em xeque, a exemplo dos mencionados Carlos Santiago Nino e Michel Troper. ${ }^{13}$

Em primeiro lugar, segundo Troper, o raciocínio de Marshall não é lógico, mas tautológico. Segundo ele, o que Marshall defende nada mais é do que o seguinte: “(1) Uma constituição é suprema (ou vinculante) se as leis inconstitucionais podem ser invalidadas; (2) Portanto, as leis inconstitucionais estão sujeitas à invalidação" (Troper, 2003:104).

Além disso, um segundo argumento contrário às "lógicas" de Marshall e Kelsen é aquele que sustenta que há uma confusão entre um problema "lógico" e um problema "prático", quando se afirma que a Constituição perderia o seu caráter de limite ao Poder Legislativo caso a lei aparentemente inconstitucional tivesse que ser aplicada sem questionamentos pelos juízes (Nino, 1996:196). Esse argumento pretende salientar que a supremacia de uma constituição não tem nenhuma relação lógica necessária com a possibilidade ou impossibilidade de que juízes possam controlar a constitucionalidade das leis. Nesse sentido, o fato de os juízes franceses não poderem controlar a constitucionalidade das leis não torna a Constituição francesa menos suprema do que outras constituições do mundo e não faz com que ela sirva menos do que essas outras constituições ao propósito do controle do poder político. ${ }^{14}$

Esse argumento tem ainda uma última consequência: mesmo que se afirme que um controle de constitucionalidade seja conveniente - porque talvez seja prudente desconfiar dos poderes e prever mecanismos para controlá-los - , esse controle não precisa ser necessariamente "judicial", como demonstra o caso francês; ou, como já salientava Pontes de Miranda há décadas: há diversas formas de proteger uma constituição rígida e o controle "judicial" de constitucionalidade é apenas uma delas. ${ }^{15}$ Ou seja: decidir sobre que tipo de controle se deseja é uma questão prática (e política) e não lógica (Nino, 1996:196), o que implica dizer que uma eventual escolha por um determinado tipo de controle de constitucionalidade deve ser feita e justificada dentro de um debate sobre desenho institucional e não a partir de um pretenso raciocínio jurídico-formal.

Esse debate e essa conclusão são importantes porque liberam o jurista para refletir sobre o controle de constitucionalidade, já que desmistificam a questão "lógica" do juiz como necessário detentor exclusivo da palavra final. Com isso, é possível fomentar o debate institucional, como se pretende fazer adiante neste trabalho.

\footnotetext{
${ }^{13}$ Cf. referências na nota 9 supra. Essa não é, contudo, uma ideia recente. Ver, por exemplo, Bittencourt, 1968:9.

${ }^{14}$ Ver, contudo, a ressalva feita adiante nas notas de rodapé 42 e 46.

${ }^{15}$ Cf. Pontes de Miranda, 1946:6 e segs. No mesmo sentido, ver, Bittencourt, 1968:9, nota 2.
} 
Mas há ainda um último argumento contra o caráter pretensamente lógico do controle judicial de constitucionalidade: se esse controle fosse, de fato, uma decorrência lógica da supremacia da Constituição, todo o debate secular sobre a legitimidade do controle de constitucionalidade, especialmente nos Estados Unidos, seria totalmente irrelevante, já que o que é logicamente cogente não necessita de legitimação normativa (Nino, 1996:190). Como esse não é o caso, parece ser necessário um exame, mesmo que breve, do debate acerca da legitimidade do controle judicial de constitucionalidade. É o que se fará no tópico a seguir.

\section{A Constituição precisa de um guardião? Variações sobre o mesmo tema}

O debate acerca da legitimidade do controle de constitucionalidade pode ser guiado por duas perguntas básicas:

A Constituição precisa de um guardião?

Em caso afirmativo, quem deve ser ele e qual deve ser a extensão de sua competência?

A primeira pergunta, acerca da necessidade de um guardião da Constituição, pode ser representada por meio de diversas dicotomias, cada qual com uma longa tradição de debates. É possível, por exemplo, dar ênfase ao embate entre procedimentalismo e substancialismo. ${ }^{16}$ É possível, também, contrapor uma visão republicana a uma visão liberal de democracia. ${ }^{17}$ É possível, ainda, encarar a questão como um embate mais amplo entre democracia e direitos individuais. A despeito da vida própria de cada uma dessas dicotomias e do diferente grau de sofisticação analítica de cada uma, todas elas estão intimamente ligadas a uma contraposição ainda mais antiga, que é aquela feita por Benjamin Constant (e retomada por Isaiah Berlin) entre a liberdade dos antigos e a liberdade dos modernos. ${ }^{18}$ Isso porque em todas elas há, de certa forma, uma polarização entre participação política (liberdade dos antigos) e garantia de uma esfera inviolável de liberdades e direitos (liberdade dos modernos).

Nesse sentido e na medida em que não é possível abordar todos esses debates neste texto, parece-me ser possível recorrer a um embate contemporâneo que resume bem as duas posições básicas em choque: a contraposição entre o fórum dos

\footnotetext{
16 Cf., por exemplo, Ely, 1980; e Tribe, 1980:1063 e segs.

17 Ver, por exemplo, Habermas, 1992 e 1994:1-13.

18 Cf. Constant, 1997:589-619 e 2002:166 e segs.
} 
princípios e a maximização da participação popular. Ou seja, a contraposição entre as ideias de Dworkin e Waldron.

De forma muito resumida, na concepção de Dworkin, uma democracia constitucional tem necessariamente duas dimensões: a da "política", na qual os membros de uma comunidade decidem em conjunto questões relativas aos interesses coletivos; e a dimensão dos "princípios", relativa à proteção dos direitos individuais dos cidadãos. ${ }^{19}$ No fórum dos princípios, cujo locus por excelência é o Judiciário - ou, mais precisamente, o tribunal de cúpula do Judiciário, ou um tribunal constitucional - , esses direitos servem como trunfos ${ }^{20}$ contra decisões de política. Daí a justificação de um controle de constitucionalidade dos atos políticos: garantir os direitos individuais contra a política e contra maiorias circunstanciais. Seria a garantia de direitos que conferiria legitimidade ao controle de constitucionalidade.

Para Waldron, contudo, justificar o controle judicial de constitucionalidade a partir da ideia de que direitos devem funcionar como trunfo contra decisões legislativas majoritárias ignoraria o desacordo moral existente em sociedades plurais, ou seja, ignoraria o fato de que as pessoas têm concepções diferentes acerca dos seus direitos mais básicos (da mesma forma que têm concepções diferentes sobre justiça social e políticas públicas). ${ }^{21}$ Em decorrência disso, isto é, em face da existência de um amplo desacordo acerca dos direitos fundamentais, a decisão sobre a questão "quem deve decidir sobre esses direitos?" deve ser tomada em igualdade de condições pelos cidadãos em uma comunidade, algo que não ocorre quando se reserva essa decisão a uma elite judiciária. Percebe-se, com isso, que a ideia de participação, especialmente a de "participação em igualdade de condições"22 é central na tese de Waldron. Não por outra razão, ele denomina o direito à participação como "o direito dos direitos". ${ }^{23}$

Esse debate, exposto de forma extremamente resumida ${ }^{24}$ e todas as outras dicotomias apontadas anteriormente costumam pecar por um certo maniqueísmo, como se o problema se resumisse às alternativas "todo poder aos juízes" ou "todo poder ao legislador". Parece-me que seria mais plausível pressupor a existência de um contínuo de possibilidades de arranjos institucionais diversos que extrapolam essa contraposição simplista. ${ }^{25}$ E é justamente essa possibilidade de diferentes ar-

${ }_{19}$ Cf. Dworkin, 1985:33 e segs. e 1996:1-38.

${ }^{20}$ Sobre a ideia de direitos como trunfos, cf. Dworkin, 1981:200.

${ }^{21}$ Cf. Waldron, 1999:11, 213 e passim.

22 Cf. Waldron, 1999:244; e Bayón, 2003:211 e segs.

${ }^{23}$ Cf. Waldron, 1999:254 e 1993:18.

24 Para uma análise mais aprofundada, cf. Mendes, 2008.

${ }^{25}$ Cf., nesse sentido, Goldsworthy, 2003:263 e segs.; e Craig, 2001:175. Ainda que em outro contexto, em sentido muito semelhante, Pontes de Miranda, 1946:8 e 1932:116. 
ranjos institucionais (que pretendem acomodar os dois termos desse debate que acabo de delinear) que tentarei explorar ao longo desta exposição.

Antes disso, porém, parece-me necessário analisar um debate paralelo àquele sobre a legitimidade do controle de constitucionalidade, que é o debate sobre o órgão que deve exercer esse controle. Nesse âmbito, a polarização paradigmática é, sem dúvida alguma, a conhecida disputa entre Kelsen e Schmitt. O primeiro, como já foi mencionado, foi o principal defensor de um tribunal constitucional como guardião da Constituição. ${ }^{26} \mathrm{O}$ segundo defendia que esse guardião deveria ser o presidente da República. ${ }^{27}$

Essa polarização, frequentemente utilizada quando se discute o controle de constitucionalidade, tem que ser vista com grandes temperamentos. ${ }^{28} \mathrm{O}$ primeiro deles decorre da clássica diferença que Schmitt fazia entre Constituição e lei constitucional, ${ }^{29}$ diferença suscitada anteriormente por Barthélemy e Duez. ${ }^{30}$ "Constituição", segundo Schmitt, seriam as decisões fundamentais de uma ordem política. " ${ }^{31}$ "Lei Constitucional" aproximar-se-ia daquilo que, muitas vezes, é chamado de Constituição em sentido formal, ou seja, o documento - ou os documentos - solenemente promulgado e hierarquicamente superior às leis ordinárias em decorrência de um processo mais difícil de emenda. ${ }^{32} \mathrm{O}$ importante é salientar que é ao primeiro conceito de Constituição que Schmitt quer fazer referência quando fala em "guardião da Constituição". Essa função - defender a ordem política e suas decisões fundamentais - "só pode ser uma função política". Assim, a defesa da Constituição, em Schmitt, não é a defesa kelseniana do dia a dia constitucional, mas uma defesa contra os inimigos da Constituição, no mais puro decisionismo schmittiano. Para ele, em um estado de guerra civil latente, reservar a guarda da Constituição a um tribunal, como queria Kelsen, poderia fazer sentido para a teoria do direito, mas politicamente seria insustentável (Pasquino, 1994:146).

Nesse sentido, percebe-se que o embate entre Kelsen e Schmitt é mais simbólico do que real. Eles não apenas falavam de conceitos distintos de Constituição, mas também de ameaças completamente diferentes. ${ }^{33}$ Em resumo, seria possível

\footnotetext{
${ }^{26}$ Cf. Kelsen, 1930/1931:576 e segs.

27 Cf. Schmitt, 1929:161-237 e 1985:132 e segs.

28 Para uma análise mais detida acerca do assunto, Pasquino, 1994:143 e segs.

${ }^{29}$ Cf. Schmitt, 1993:11 e segs.

${ }^{30}$ Cf. Barthélemy e Duez, 1926:41. O próprio Schmitt menciona a distinção feita por Barthélemy e Duez (cf. Schmitt, 1993:15).

${ }^{31}$ Cf. Schmitt, 1993:20 e segs.

${ }^{32}$ Cf. Schmitt, 1993:11e segs. Nesse sentido, cf., também, Jellinek, 1914:534. É necessário salientar, contudo, que Schmitt faz menção também a uma diferença entre Constituição em sentido formal e lei constitucional em sentido formal (p. 12 e segs.). No entanto, para os fins deste texto, essa distinção não precisa ser analisada.

${ }^{33}$ Como diria Schmitt (1985:100) duas décadas depois sua tese sobre o guardião da Constituição foi feita na Berlim do início da década de 1930, imediatamente anterior ao colapso da República de Weimar e
} 
dizer, seguindo as palavras de Zagrebelsky, que a disputa entre Kelsen e Schmitt é o embate entre o controle de constitucionalidade do dia a dia contra a guarda da Constituição contra ameaças ao regime político. ${ }^{34}$ Assim, não há, de fato, disputa, pois ambos constituem momentos distintos da ideia de defesa da Constituição. ${ }^{35}$

Mas, embora relativizada, a querela entre Schmitt e Kelsen toca ainda assim em um ponto nevrálgico da questão, que ainda permanece atual: quem deve ser o guardião da Constituição? Ainda que possamos pensar que, no Brasil, em virtude de previsão expressa da Constituição, essa é uma questão superada e que o guardião da Constituição é o Poder Judiciário, especialmente na figura do STF, essa seria uma visão apenas parcial do problema. A própria discussão sobre modelos de controle reinsere a questão na pauta de debates constitucionais. Como se verá a seguir, cada um dos modelos dá ênfase a um tipo guardião da Constituição.

\section{Distinções entre modelos de controle: para além dos binômios prévio/posterior e difuso/concentrado}

No Brasil, o debate sobre controle de constitucionalidade, em seu aspecto institucional, costuma resumir-se pura e simplesmente à exposição das possíveis combinações decorrentes de dois binômios básicos: controle prévio versus controle posterior e controle difuso versus controle concentrado. Porém, imaginar que o que diferencia, por exemplo, o sistema francês do sistema norte-americano é simplesmente o caráter prévio e concentrado (abstrato) do primeiro ${ }^{36}$ em face do caráter posterior e difuso (concreto) do segundo é algo um tanto quanto redutor. Há outras diferenças entre ambos os sistemas que, para os fins deste trabalho, podem ser mais interessantes do que essas.

Ao afirmar isso, contudo, não pretendo pura e simplesmente apresentar uma classificação diferente da tradicional. Não há nada de equivocado em si mesmo na utilização didática dos três modelos ideais - norte-americano, austríaco-alemão e francês - , ou no uso dos binômios básicos supracitados. Mas, como ainda se verá ao longo deste trabalho, dar a devida atenção a outras diferenças - às vezes

\footnotetext{
à ascensão do nacional-socialismo ao poder, fato que, segundo alguns autores, indicaria tratarem-se de ideias aplicáveis àquele momento histórico. Nesse sentido, cf. Pasquino, 1994:147.

34 Cf. Zagrebelsky, 1977:32. Em sentido semelhante, cf. Jestaedt, 2007:161.

35 Pasquino usa a Constituição francesa de 1958 para demonstrar a existência de momentos distintos da guarda da Constituição. Há a guarda cotidiana, a cargo do Conselho Constitucional, e há a guarda excepcional, conferida ao presidente da República, no exercício de seus poderes de emergência garantidos pelo art. 16. Cf. Pasquino, 1994:148.

36 Embora, em julho de 2008, uma reforma na Constituição francesa tenha introduzido a possibilidade de controle judicial de constitucionalidade a posteriori (cf., sobre o assunto, nota de rodapé 46), isso em nada altera o raciocínio desenvolvido no texto.
} 
consideradas secundárias ou até mesmo ignoradas - pode ser importante na reflexão institucional sobre o controle de constitucionalidade, já que quase sempre que se pensa em reformular o modelo brasileiro, o debate concentra-se apenas na alternativa entre controle difuso e controle concentrado.

Para se ter uma pequena ideia das inúmeras diferenças entre o modelo norteamericano e o modelo austríaco-alemão (ou continental europeu ${ }^{37}$ ), se torna necessário fazer um quadro esquemático. ${ }^{38}$

\section{Diferenças entre o modelo continental europeu e o modelo norte-americano}

\begin{tabular}{|c|c|}
\hline Modelo continental europeu & Modelo norte-americano \\
\hline Fenômeno pós-autoritário. & $\begin{array}{l}\text { Fenômeno ligado à formação de um sistema } \\
\text { político e de autoafirmação do Judiciário. }\end{array}$ \\
\hline Juízes com mandatos. & Juízes vitalícios. \\
\hline $\begin{array}{l}\text { Monopólio da decisão sobre } \\
\text { inconstitucionalidade (sistema concentrado). }\end{array}$ & $\begin{array}{l}\text { Ausência de monopólio da decisão sobre } \\
\text { inconstitucionalidade (sistema difuso). }\end{array}$ \\
\hline Raramente há audiências ou sustentações orais. & A regra é a existência de audiências orais. \\
\hline Juízes decidem em sessões secretas. & Juízes decidem em sessões abertas. \\
\hline $\begin{array}{l}\text { Decisão coletiva e unitária, geralmente sem } \\
\text { votos divergentes. }\end{array}$ & $\begin{array}{l}\text { Decisões individuais, que, ao final, são somadas } \\
\text { para se obter a decisão final, com publicação de } \\
\text { opiniões divergentes. }\end{array}$ \\
\hline $\begin{array}{l}\text { Nomeações de juízes costumam exigir grandes } \\
\text { maiorias parlamentares (o que fomenta o } \\
\text { consenso entre as forças políticas). }\end{array}$ & $\begin{array}{l}\text { Nomeações pelo presidente, com aprovação } \\
\text { por maioria simples no Senado (juízes costumam } \\
\text { ficar identificados com um partido ou } \\
\text { presidente). }\end{array}$ \\
\hline Decisões em geral sobre questões abstratas. & Decisões sobre casos concretos. \\
\hline
\end{tabular}

Como se pode perceber, não são poucas as diferenças entre ambos os modelos. ${ }^{39}$ Algumas delas, como salientado, serão ainda exploradas nos tópicos seguintes. Antes disso, contudo, é importante fazer referência ao modelo francês, já que ele também costuma ser utilizado como um modelo ideal, por ser a expressão mais conhecida de um controle prévio de constitucionalidade. ${ }^{40}$

\footnotetext{
37 Para facilitar a análise, a rubrica "modelo continental europeu" será utilizada aqui, mesmo sabendose que há diferenças entre os diversos sistemas nacionais de controle de constitucionalidade existentes na Europa. A ideia é fazer referência a um "tipo ideal".

38 Cf. Ferejohn e Pasquino, 2004:1677 e segs. e 2002:33 e segs.

${ }^{39}$ Se, ao invés de se comparar o modelo norte-americano com um modelo "ideal" continental-europeu, a comparação for feita com modelos europeus específicos, a lista de diferenças pode ser, em alguns casos, ainda maior (e, em outros, menor, já que alguns países da Europa possuem sistemas de controle de constitucionalidade que se aproximam mais do modelo norte-americano).

40 As considerações feitas a seguir têm como pano de fundo a situação do modelo francês na época da apresentação deste trabalho como prova de erudição no concurso mencionado na primeira nota de
} 
Não é possível inserir o sistema francês em uma das duas colunas da tabela supra. Mais do que isso: não bastaria inserir uma informação sobre o caráter prévio do sistema francês para acomodá-lo em algum lugar. Quando são rejeitadas - como é o caso neste artigo - classificações baseadas apenas nos binômios "prévio $x$ posterior" e "concentrado $x$ difuso", e quando se intenta fazer uma análise mais detalhada das reais diferenças entre os grandes modelos existentes (por exemplo, com base nas oito diferenças apontadas na tabela supra), fica claro por que o sistema francês não pode ser incluído nessa classificação. As razões principais são as seguintes:

o controle francês não é um controle "judicial" de constitucionalidade;

o Conselho Constitucional é órgão político, quase uma terceira casa legislativa,

os membros do Conselho Constitucional são políticos, ${ }^{42}$ indicados diretamente pelo presidente da República, pelo presidente da Assembleia Nacional e pelo presidente do Senado;

o modelo francês é uma tentativa de conciliação entre a tradição francesa de soberania parlamentar (que levou, entre outras coisas, à rejeição do Jury Constitutionnaire, de Sieyès) e uma eventual necessidade de controle, especialmente aquela surgida no contexto político-constitucional do fim da década de 1950,43

no sistema francês, não há uma instância deliberativa, uma instância da qual seja exigida uma "deliberação" extensiva e uma fundamentação exaustiva e sofisticada, já que o Conselho Constitucional decide como órgão político, sem que haja grandes motivações, e tem, em geral, no máximo um mês para decidir (às vezes reduzido para oito dias $\left.{ }^{44}\right)$.

rodapé deste texto (setembro de 2006). Não serão analisadas, portanto, as mudanças decorrentes da reforma constitucional de 23 de julho de 2008, que acrescentou, entre outras mudanças, a possibilidade de controle judicial constitucionalidade a posteriori, por via de exceção, na França (cf. o novo art. 61-1, da Constituição francesa). Mas, na medida em que o controle por excelência continua a ser aquele já existente anteriormente, as considerações feitas no texto não perdem sua validade.

${ }^{41}$ Nesse sentido, Stone, 1992:108-110 e 209 e segs.; Avril e Gicquel, 2005:139 (“o controle [...] constitui não um contencioso, mas uma 'votação complementar da lei'”). Em sentido contrário, cf. Favoreu, 1988:109-138 e Vedel, 1989:50. Disponível em: <www.conseil-constitutionnel.fr/conseil-constitutionnel/root/ bank/print/25707.htm>.

42 Quando se fala que os membros são "políticos", o termo não é utilizado no sentido político-partidário. Vários membros do Conselho Constitucional são professores universitários. Quando se fala em "político", quer-se fazer menção a uma relação mais direta entre os membros do Conselho e os poderes políticos que os indicaram, visto que, ao contrário do que ocorre nos outros modelos, no modelo francês não há qualquer forma de freios e contrapesos na indicação dos membros do Conselho Constitucional.

43 Nas palavras de Dominique Rousseau, a criação do Conselho Constitucional foi a junção de duas vontades: uma "positiva" - conter o Parlamento - , e uma "negativa" - evitar a adoção de um verdadeiro controle judicial de constitucionalidade. Cf. Rousseau, 1999:24 e segs.

${ }^{44}$ Cf. art. 61 da Constituição francesa e art. 25 da Lei Orgânica do Conselho Constitucional. 
Essa última característica - a ideia de deliberação - é central para este trabalho e será explorada a seguir. Neste ponto, o importante é perceber que o caráter prévio do controle francês tem importância reduzida. O que o diferencia de todos os outros modelos é também o seu caráter político e não deliberativo. Essa constatação, e sua relação com os modelos expostos na tabela anteriormente apresentada, conduzem ao ponto seguinte.

\section{A necessidade de diálogo constitucional: deliberação e razão pública, pensamento institucional e modelos alternativos}

Nos últimos tempos, um dos principais debates no âmbito da ciência política, da filosofia e do direito constitucional é aquele em torno da ideia de democracia deliberativa. ${ }^{45}$ Em geral, o foco desse debate são os poderes políticos - Legislativo e Executivo - e a sociedade civil organizada. Muito raramente, o Poder Judiciário é incluído na discussão. Na verdade, costuma ocorrer justamente o oposto: o Poder Judiciário costuma ser considerado como antidemocrático e antideliberativo por excelência. No entanto, a despeito do inegável caráter contramajoritário do Poder Judiciário no exercício do controle de constitucionalidade, parece-me haver um potencial ainda pouco explorado no que diz respeito à interação do controle de constitucionalidade com as práticas deliberativas.

Nesse ponto, é sugestiva a ideia de Rawls, segundo a qual a Suprema Corte dos Estados Unidos e tribunais assemelhados têm tudo para ser o locus por excelência da deliberação racional e da razão pública. ${ }^{46}$ Ao contrário do que ocorre com os poderes políticos - e mesmo com a sociedade civil organizada - os membros de um tribunal não podem invocar sua moralidade, sua religiosidade e suas ideologias pessoais para fundamentar suas decisões. As decisões de um tribunal de cúpula - como a Suprema Corte dos Estados Unidos, os tribunais constitucionais europeus e o Supremo Tribunal Federal - têm que refletir valores políticos de justiça e razão pública (Rawls, 1993:235-236). Para isso, o papel da deliberação é fundamental.

A partir dessa ideia, Ferejohn e Pasquino elaboram uma comparação entre os modelos norte-americano e europeu de controle de constitucionalidade baseada em premissas diferentes das usuais, centradas sobretudo no binômio concentra-

\footnotetext{
45 Cf., por exemplo, Habermas, 1962 e 1992; Rawls, 1993; Cohen, 1989:17-34; Nino, 1996; Gutmann e Thompson, 2004. Ver também as contribuições publicadas em Elster, 1998.

${ }^{46}$ Cf. Rawls, 1993:231 e segs. Para um desenvolvimento posterior da ideia de razão pública, ver Rawls, 1997:765 e segs.
} 
ção/difusão. ${ }^{47}$ Para eles, quando se entende o controle de constitucionalidade como uma parte integrante do processo legislativo em sentido amplo e de interpretação da Constituição, a diferença principal entre esses dois modelos desloca-se para a contraposição entre duas formas distintas de deliberação: a deliberação "interna" e a deliberação "externa". ${ }^{8}$

\section{Deliberação interna e deliberação externa}

Segundo Ferejohn e Pasquino (2004:1692), a deliberação interna envolve a troca de razões e argumentos no interior de um grupo, no intuito de fazer com que esse grupo, como um todo, decida em uma determinada direção. A deliberação externa consiste no esforço de convencer atores externos ao grupo. No caso dos tribunais, então, a deliberação interna diz respeito ao fluxo de argumentos entre os juízes, ou seja, no interior do próprio tribunal; a deliberação externa diz respeito ao fluxo de argumentos entre o tribunal e o mundo externo a ele.

A partir dessa distinção, e da tabela apresentada supra, é possível perceber uma diferença crucial entre os modelos europeu e norte-americano: no primeiro, a deliberação é sobretudo "interna"; no segundo, é "externa". ${ }^{49}$ Como apontado anteriormente, no modelo europeu raramente há audiências e sustentações orais, os juízes não dialogam com advogados e, o que mais importa, as decisões são tomadas a portas fechadas, em muitos casos sem a possibilidade de votos divergentes. Quais são as consequências desse modelo de deliberação? A principal delas reside no fato de que os juízes, ao decidir em conjunto, sem grandes possibilidades de divergência, argumentam internamente, sem se expor individualmente para o exterior e podem tentar - e sempre tentam - chegar a uma decisão "única", "institucional", "clara", "objetiva" e de "consenso". Isso reforça, na análise de Ferejohn e Pasquino, o caráter verdadeiramente deliberativo do tribunal encarregado do controle. Em outras palavras, pode-se dizer que a persuasão interna força o diálogo. Isso pode ser percebido de forma precisa em uma declaração de Dieter Grimm, ex-juiz do Tribunal Constitucional Federal alemão:

\footnotetext{
${ }^{47}$ Cf. Ferejohn e Pasquino, 2002:35 e 2004:1692 e segs.

${ }^{48}$ Cf. também a análise de Lasser, que compara as práticas deliberativas na França, nos Estados Unidos e na União Europeia (cf. Lasser, 2004:241 e segs.). Embora sua análise não tenha como foco o controle de constitucionalidade, algumas de suas conclusões aproximam-se, em alguns aspectos, das conclusões de Ferejohn e Pasquino. Outras, no entanto, vão em direção diversa, especialmente aquelas que dizem respeito aos efeitos dos votos abertos e individuais dos juízes norte-americanos na transparência do processo decisório (cf., por exemplo, p. 302 e 338).

${ }^{49}$ Como fica claro no texto, fala-se em deliberação "sobretudo" externa, ou "sobretudo" interna, já que não é possível, de fato, afirmar que em um tribunal exista apenas um tipo de deliberação.
} 
diferente do que ocorre na Suprema Corte dos Estados Unidos, no Tribunal Constitucional alemão há sempre uma longa deliberação sobre questões controversas. Argumentos contam e, com frequência, juízes mudam suas opiniões como resultado da deliberação (...). Estou convencido de que essa experiência contribui para reduzir o número de votos divergentes. Se todos cederam e alguma forma de conciliação foi alcançada, há uma menor motivação para insistir em um voto divergente, mesmo quando não se concorde totalmente com a decisão final. ${ }^{50}$

No caso americano, juízes praticamente não interagem entre si e não deliberam no sentido estrito da palavra. O trabalho é individual e isolado. É possível indagar, como o fazem Ferejohn e Pasquino, se, de fato, os juízes da Suprema Corte americana têm como objetivo primordial persuadir seus colegas acerca da correção de suas opiniões. Utilizando o juiz Scalia como exemplo, os autores afirmam que ele claramente não pretende, com seus votos divergentes estridentes, convencer seus colegas de tribunal. "Sua plateia está em outro lugar", sua plateia é externa: é o Congresso, a Casa Branca, as faculdades de direito, são os jornalistas. ${ }^{51}$

Nesse ponto da exposição, seria possível indagar qual tipo de deliberação judicial uma democracia constitucional necessita? Parece-me que de ambos. Mas - e aqui me desvio da análise de Ferejohn e Pasquino - as deliberações dos tipos interno e externo não precisam necessariamente ocorrer das formas descritas supra, até porque elas seriam, em grande medida, incompatíveis entre si.

Assim, de um lado, é preciso que um tribunal superior, no exercício do controle de constitucionalidade, fale "como instituição", de forma "clara", "objetiva”, "institucional" e, sempre que possível, "única". Esse é o papel da deliberação interna. Ou seja: especialmente o objetivo de se alcançar uma decisão institucional e única parece ser possível apenas por meio de uma deliberação do tipo interno. Já o papel da deliberação externa - que seria sobretudo o de chamar a atenção da sociedade civil, ou pelo menos da comunidade acadêmica e jornalística, para questões fundamentais no cenário político-jurídico de um país - que também é de extrema importância, pode ser exercido de outra forma. Ou seja: o diálogo entre tribunal e sociedade civil, ou entre tribunal e poderes políticos, não precisa ser feito por meio de uma fragmentação da deliberação e de uma desagregação argumentativa, que são, na minha opinião, características da deliberação externa. A meu ver, a tarefa de diálogo entre o tribunal e outros autores - quaisquer que sejam - pode ser exercida tanto pelos juízes no seu atuar individual fora do tribu-

50 Cf. Ferejohn e Pasquino, 2004:1695-1696. A declaração está contida em e-mail enviado por Dieter Grimm aos autores do texto.

${ }^{51}$ Cf. Ferejohn e Pasquino, 2004:1.697. Sobre a ideia de audiência externa, ver, também, Baum, 2007. 
nal quanto - e mais importante para os objetivos deste trabalho - por meio do diálogo entre poderes, de um "diálogo constitucional".

Diante disso, estabelecem-se duas formas importantes de diálogo. A primeira - o diálogo interno - ocorre por meio da deliberação dos juízes entre si, seguindo o modelo continental europeu. Mas como atingir a segunda forma de diálogo, o diálogo externo? Como suscitar um diálogo entre os poderes constitucionais? A resposta a essa pergunta exige a análise de algumas formas alternativas de controle judicial de constitucionalidade.

\section{Controle forte e controle fraco}

Um dos principais debates contemporâneos sobre controle de constitucionalidade é a discussão institucional acerca do que se convencionou classificar de formas fortes e formas fracas de controle de constitucionalidade. Nos últimos anos, vários trabalhos foram publicados especificamente sobre o tema, tanto nos Estados Unidos $^{52}$ quanto na Europa, ${ }^{53}$ quanto na Austrália. ${ }^{54}$ Isso sem contar a vasta literatura canadense sobre o tema, já que o modelo canadense costuma ser apontado como o paradigma de modelo alternativo. ${ }^{55}$

O ponto de partida desse debate deve ser, seguindo a proposta de Jeremy Webber, a superação da ideia de que controle de constitucionalidade é simplesmente a submissão das leis à guilhotina anuladora judiciária. ${ }^{56}$ Há um potencial muito maior - e muitas vezes inexplorado - nesse âmbito, que é o "diálogo entre Judiciário e legislador". ${ }^{57}$ A possibilidade desse diálogo tem relação direta com a facilidade ou a dificuldade daquilo que se convencionou chamar de "superação legislativa" (legislative override), ${ }^{58}$ ou seja, da faculdade de o legislador rediscutir as decisões tomadas no âmbito do controle judicial de constitucionalidade e, se for o caso, de superá-las.

\footnotetext{
${ }^{52}$ Cf., por exemplo, Tushnet, 2003:2781 e segs. e 813 e segs.; Sinott-Armstrong, 2003:381 e segs.

${ }^{53}$ Cf. Lebeck, 2005:55 e segs. e Hickman, 2005:306 e segs.

${ }_{54}$ Cf. Goldsworthy, 2003:263 e segs.

${ }^{55}$ Cf., por exemplo, Hogg e Bushell, 1997:75 e segs.; Roach, 2001:481 e segs., 2004:49 e segs. e 2006:347 e segs.; Webber, 2002:61 e segs. No primeiro semestre de 2007, a revista Osgoode Hall Law Journal publicou um número especial sobre a discussão canadense acerca da ideia de diálogo entre corte e poderes políticos. Cf. Osgoode Hall Law Journal (2007).

56 Cf. Webber, 2002:64.

57 Fora do cenário canadense, cf., sobre a ideia de diálogo, Fisher, 1988. Para uma aplicação da ideia de diálogo no caso do processo legislativo brasileiro, cf. Sampaio, 2007:95 e segs.

58 "Legislative override" também poderia ser traduzido por "revogação legislativa". Como não se trata, contudo, de uma revogação no sentido técnico-jurídico do termo, já que um ato do legislativo não revoga uma decisão judicial, preferi o termo "superação legislativa".
} 
A partir desse ponto de vista, modelos como o norte-americano e os da grande maioria dos países europeus podem ser considerados como modelos "fortes" de controle de constitucionalidade. Isso porque uma eventual superação de uma decisão de inconstitucionalidade pela Suprema Corte ou por um tribunal constitucional só poderia ocorrer se fosse emendada a Constituição, o que costuma ser algo difícil e excepcional, sobretudo - mas não apenas — nos Estados Unidos. ${ }^{59}$

Modelos como o canadense e o inglês (após a entrada em vigor do Human Rights Act) são modelos fracos de controle de constitucionalidade. ${ }^{60}$ No caso canadense, porque o legislador pode, após uma decisão judicial de inconstitucionalidade, promulgar novamente a lei declarada inconstitucional e imunizá-la temporariamente contra futuras decisões judiciais de inconstitucionalidade (e renovar, se quiser, essa "imunidade" a cada cinco anos). No caso inglês, as decisões de controle de constitucionalidade, instituído pelo Human Rights Act, de 1998, não vinculam totalmente o legislador, sendo apenas decisões de incompatibilidade, mas não de invalidade. ${ }^{61}$

Em ambos os casos, como se percebe, o legislador tem a possibilidade de reabrir o diálogo, se assim entender conveniente. Ou seja: ele pode aceitar a decisão do Judiciário, mas pode também superá-la. É essa possibilidade de superação que é chamada de "legislative override".

Aqueles menos habituados ao diálogo poderiam, de pronto, alegar que, se a última palavra é do legislador, seria como se não houvesse nenhum controle, ou seja, estaríamos diante de um modelo de soberania do Parlamento. Essa é, contudo, uma análise equivocada da questão. E isso por três razões principais.

Em primeiro lugar, porque ela ignora o valor do debate. Decidir em única e última instância (soberania parlamentar) é muito diferente de decidir após o pronunciamento de um tribunal em um determinado sentido (contrário às intenções do legislador). A decisão do tribunal necessariamente cria um "ônus deliberativo", que muitas vezes é difícil de ser superado. O diálogo, além disso, tem outra função importantíssima: desacelerar o debate político. Ele faz com que decisões legislativas tomadas em momentos de crises circunstanciais possam ser repensa-

\footnotetext{
59 Daí a distinção feita por Bruce Ackerman, no âmbito de seu conceito de dualismo constitucional, entre a política ordinária, do dia a dia, e a política constitucional, que ocorre em raríssimos momentos, quando se pretende mudar a Constituição. Cf. Ackerman, 1993:13 e segs.

${ }_{60}$ Além dos modelos canadense e inglês, pode-se fazer menção também ao modelo neozelandês. No caso da Nova Zelândia, o controle é ainda mais fraco, já que a declaração de direitos de 1990 não tem status de lei superior às leis ordinárias, não servindo, assim, como parâmetro para a declaração de inconstitucionalidade de leis posteriores. O que essa declaração de direitos exige é apenas que a legislação seja interpretada sempre da forma mais compatível com a proteção dos direitos nela previstos. Para mais detalhes sobre o controle de constitucionalidade na Nova Zelândia, cf. Gardbaum, 2001:727 e segs. e Butler, 1997:325-345.

${ }^{61}$ A esse respeito, cf. Bamforth, 1998:572-582.
} 
das, sobretudo diante dos ponderados argumentos de uma suprema corte ou de um tribunal constitucional.

Em segundo lugar, imaginar que a possibilidade de o legislador superar as decisões judiciais é equivalente à inexistência de controle é equivocado porque ignora a experiência concreta. No Canadá, por exemplo, onde o modelo já existe há mais tempo, estudos demonstram que, apesar de ter a competência para tanto, o Legislativo quase nunca se utiliza desse expediente. ${ }^{62}$ A existência de uma decisão de um tribunal de cúpula cria um "ônus político" para a sua superação que os legisladores poucas vezes estão dispostos a enfrentar, especialmente nos casos mais polêmicos. Ao insistir em uma lei declarada inconstitucional pelo Judiciário, e ainda imunizá-la contra revisões judiciais posteriores, o legislador geraria a impressão de agir inconstitucionalmente, peso que ele, em geral, não estaria disposto a carregar.

Em terceiro lugar, por fim, pensar que a possibilidade de superação legislativa de decisões judiciais de inconstitucionalidade seria conferir a última palavra ao legislador é equivocado porque compreende o controle de constitucionalidade como processo apenas no sentido jurídico-formal da palavra, ou seja, apenas no sentido dado pelo direito processual. Se se compreende o controle de constitucionalidade como um processo de diálogo, logo se percebe que esse diálogo, ao contrário do processo em sentido jurídico-formal, não tem fim. $\mathrm{O}$ diálogo está sempre aberto a novos argumentos, seja por parte do legislador, seja por parte dos tribunais, seja por parte da sociedade civil.

Nesse ponto, seria possível indagar como caracterizar o modelo brasileiro no debate entre formas fracas e formas fortes de controle, ou seja, no debate entre modelos que permitem maior diálogo e modelos que permitem menor diálogo entre Judiciário e legislador? A resposta a essa pergunta encontra-se nos tópicos finais deste artigo.

\section{O modelo brasileiro no contexto do debate}

Como se sabe, o modelo brasileiro surge, com a Proclamação da República, inspirado claramente no modelo norte-americano. Ainda antes da promulgação da Constituição de 1891, o Decreto no 848/1890 já previu a competência dos juízes para não aplicar a lei entendida como inconstitucional. O Supremo Tribunal Federal também é criado, inspirado na Suprema Corte dos Estados Unidos. Se

\footnotetext{
${ }^{62}$ Cf., por exemplo, Goldsworthy, 2003:274 e segs. E para um aprofundado estudo empírico sobre o uso desse expediente no Canadá, veja Kahana, 2001:255 e segs.
} 
usarmos a classificação tradicional, o sistema de controle de constitucionalidade criado no início da República era um sistema claramente "difuso" e de controle "posterior" da lei.

No início dessa fase republicana, tanto os juízes ordinários quanto os próprios ministros do Supremo Tribunal Federal hesitavam em exercer a sua competência de controle, por entenderem que, na maioria das vezes, ela seria uma afronta à separação de poderes, uma invasão de área reservada à política. ${ }^{63}$ Nesse período, para a consolidação do controle de constitucionalidade no Brasil, foram decisivas as ações de dois juristas do início da República. Um deles foi Rui Barbosa, sobretudo em alguns habeas corpus que questionavam medidas tomadas sob os constantes estados de sítio decretados durante a Primeira República (como os habeas corpus 300 e 1.063), quem exerceu grande influência como advogado e orador. ${ }^{64}$ Mas a consolidação do controle de constitucionalidade no Brasil também se deve aos votos do ministro Pedro Lessa, durante sua atuação no Supremo Tribunal Federal. ${ }^{65}$

Depois de consolidada a competência judicial para controlar a constitucionalidade das leis no Brasil e depois de décadas fiel ao modelo norte-americano, o sistema brasileiro passou a sofrer um longo "processo de concentração". Os anoschave desse processo foram: 1934, 1965, 1988, 1993, 1999 e 2004 . Em 1934 cria-se a primeira forma de ação direta de inconstitucionalidade, limitada ainda apenas aos casos de intervenção federal. Em 1965 é criada a figura da representação de inconstitucionalidade, por meio de uma emenda à ainda vigente Constituição de 1946. Essa representação era uma possibilidade de acessar diretamente o Supremo Tribunal Federal para decidir sobre a constitucionalidade, em abstrato, de uma lei. Sua principal limitação era a competência para a sua propositura, restrita ao procurador-geral da República. Com a promulgação da Constituição de 1988 houve

\footnotetext{
${ }^{63}$ Cf., por exemplo, as decisões nos habeas corpus 300 (de 1892), 1.063 e 1.073 (ambos de 1898). No HC 1.063, lê-se: "Esta é a única interpretação que se adapta ao nosso direito constitucional, que não permite ao Poder Judiciário dilatar a esfera da sua jurisdição para se imiscuir nas funções políticas do Presidente da República" (Revista de Jurisprudência, 3 [1898], p. 71).

${ }^{6}$ Cf. a petição inicial no habeas corpus 300, publicada em obra de Rui Barbosa, Estado de sítio, 1892, p. 3 e segs., especialmente p. 20. Sua defesa do controle de constitucionalidade pode também ser notada por meio de diversos escritos esparsos. Cf. Rui Barbosa, A constituição e os atos inconstitucionais, s.d. e, do mesmo autor, Comentários à Constituição Federal brasileira, p. 127 e segs.

65 Cf. a opinião (vencida) de Pedro Lessa no habeas corpus 3.527 (de 1914): “O art. 59, parágrafo 1o e o artigo 60 da Constituição conferem positivamente ao Supremo Tribunal Federal a faculdade de declarar inconstitucionais as leis elaboradas pelo Poder Legislativo, e inconstitucionais ou ilegais os atos do Poder Executivo (...). O Poder Legislativo nacional pode votar todas as leis que lhe parecerem necessárias ou úteis, menos as leis inconstitucionais. (...) Esqueça-se, portanto, de uma vez para sempre, a fútil objeção de que o Supremo Tribunal Federal não se pode ocupar de questões políticas. Pode, indubitavelmente" (Revista do Supremo Tribunal Federal, 1 [1914], p. 68). Cf., também, Lessa, 1915:54 e segs.: "Quais são as questões exclusivamente políticas? (...) Quando a função de um poder, Executivo ou Legislativo, não corresponde, ou, antes, não se opõe um direito, de uma pessoa, física ou moral (...)" (p. 59). O embate entre democracia e proteção de direitos, brevemente exposto no tópico 2, pode ser percebido com toda clareza no pensamento de Pedro Lessa.
} 
inúmeras alterações no modelo brasileiro, todas elas, de certa forma, dando mais poderes ao Supremo Tribunal Federal. Criou-se a ação direta de inconstitucionalidade - com uma lista muito mais ampla de legitimados para sua propositura - o mandado de injunção, a ação direta de inconstitucionalidade por omissão e a arguição de descumprimento de preceito fundamental. Em 1993 cria-se, por meio da Emenda Constitucional no 3, a ação declaratória de constitucionalidade. Em 1999, por meio das leis nos 9.868 e 9.882, é regulamentado com maior clareza procedimental todo o processo de controle de constitucionalidade no Brasil, com uma clara tendência "concentradora" e "vinculante" do controle de constitucionalidade exercido pelo STF. ${ }^{66}$ Por fim, em 2004, com a Emenda Constitucional no 45, cria-se a súmula vinculante e a exigência de demonstração de repercussão geral para a admissibilidade do recurso extraordinário no STF. Não é o caso de analisar a fundo nenhuma dessas ações, mas apenas apontar para o fato de que elas são responsáveis por uma concentração do controle de constitucionalidade nas mãos do Supremo Tribunal Federal. Se em 1891 não havia nenhuma forma de recorrer diretamente ao STF para obter uma decisão sobre a constitucionalidade ou a inconstitucionalidade de uma lei, hoje há pelo menos cinco.

Mas - e isso é fundamental para a tese defendida neste texto - , ao contrário do que se poderia pensar, o caminho para a concentração "não significou um caminho para o modelo europeu". Aquele que imagina que a evolução brevemente exposta no parágrafo supra está transformando o Supremo Tribunal Federal em um tribunal constitucional de tipo continental europeu, assim o faz porque está preso aos binômios prévio-posterior e difuso-concentrado. Como o sistema brasileiro já era a posteriori como o europeu, a única variável que então os diferenciaria seria, ainda segundo essa linha de pensamento, a maior concentração de competências dos tribunais constitucionais europeus. Com o aumento dessa concentração também no Brasil, o Supremo Tribunal Federal estaria a um passo de se transformar em um tribunal constitucional por excelência.

Essa é, no entanto, uma análise que me parece equivocada. A evolução brevemente apresentada supra mostra que as únicas concessões ao sistema continental europeu são a possibilidade de ações diretas de controle abstrato e algumas formas de vinculação das decisões do STF. Todo o resto - i.e., a forma de nomeação dos ministros, sua vitaliciedade, as sessões públicas e as sustentações orais, a publicação de votos divergentes como regra e não como exceção e, sobretudo, a "forma de decisão", individual e não concatenada - continuam a ser como sempre

\footnotetext{
${ }^{66}$ Por exemplo, com a previsão, pelo art. 28 da Lei nº 9.868/1999, de efeitos vinculantes até mesmo para a interpretação que o Supremo Tribunal Federal der a algum dispositivo legal. Para isso, basta que o tribunal a classifique como "interpretação conforme a Constituição". Sobre isso e sobre essa tendência concentradora, cf. Silva, 2006:191 e segs.
} 
foram, ou seja, uma cópia - às vezes bem-feita, às vezes malfeita - do modelo norte-americano.

E isso, como se viu ao longo de todo o texto, tem consequências importantes, já que valem para o modelo brasileiro todas as considerações feitas sobre o modelo norte-americano quando foram contrapostas as noções de deliberação "interna" e deliberação "externa". O modelo brasileiro pode ser considerado como um modelo extremo de deliberação externa, o que o afasta definitivamente dos modelos continentais europeus. ${ }^{67}$ Especialmente devido à:

quase total ausência de trocas de argumentos entre os ministros: nos casos importantes, os ministros levam seus votos prontos para a sessão de julgamento e não estão ali para ouvir os argumentos de seus colegas de tribunal;; ${ }^{68}$

inexistência de unidade institucional e decisória: o Supremo Tribunal Federal não decide como instituição, mas como a soma dos votos individuais de seus ministros; ${ }^{69}$

carência de decisões claras, objetivas e que veiculem a opinião do tribunal: como reflexo da inexistência de unidade decisória, as decisões do Supremo Tribunal Federal são publicadas como uma soma, uma "colagem", de decisões individuais; muitas vezes é extremamente difícil, a partir dessa colagem, desvendar qual foi a real razão de decidir do tribunal em determinados casos, já que, mesmo os ministros que votaram em um mesmo sentido podem tê-lo feito por razões distintas.

Além disso, na contraposição entre modelos "fracos" e modelos "fortes" de controle de constitucionalidade, ou seja, entre modelos que permitem maior e menor diálogo entre os poderes, o modelo brasileiro poderia ser considerado como "ultraforte". Isso porque, além de reunir as características típicas dos modelos for-

\footnotetext{
${ }^{67} \mathrm{O}$ fato de muitas das sessões de julgamento do STF serem transmitidas ao vivo pela TV Justiça apenas agrava esse quadro. Quanto mais aberta a sessão - e a transmissão pela televisão é um escancaramento -, menor tende a ser a deliberação interna.

${ }^{68}$ Esse fato é agravado pela regra regimental (art. 135), segundo a qual os ministros votam sempre na mesma ordem (ordem inversa de antiguidade). O primeiro a votar, após o relator, é o ministro mais novo na casa e o último, antes do presidente, é o mais antigo. Ou seja: muitas vezes, quando são lidos os votos dos ministros mais antigos, o caso já está decidido.

${ }^{69}$ É claro que, nesse ponto, alguém poderia sustentar que não há nada de errado com esse sistema, já que ele é o sistema decisório por excelência em órgãos colegiados. Ou seja: o Supremo Tribunal Federal decide da mesma forma que decidem a Câmara dos Deputados e o Senado Federal, por meio de uma espécie de "placar final". Ora, mas se o que legitima a possibilidade de controle judicial de constitucionalidade é justamente a deliberação e a busca por uma razão pública, não faz sentido que a forma de decisão do STF seja igual àquela dos poderes políticos. Não faz sentido que os argumentos não tenham nenhuma importância - e, na prática atual do STF, eles muitas vezes não têm, já que os ministros decidem isoladamente, antes de ouvir os argumentos de seus colegas.
} 
tes, o Brasil tem uma constituição com um amplo rol de dispositivos imodificáveis, as chamadas "cláusulas pétreas". Ou seja, no caso brasileiro, o Supremo Tribunal Federal, em muitos casos, não pode nem mesmo exercer o papel de indicador de via alternativa, ou, para usar a metáfora usada por Favoreu, de "guarda-chaves" (guarda-chaves, nas ferrovias, é o empregado encarregado de manobrar as chaves nos desvios ou entroncamentos das linhas). ${ }^{70}$ Assim, ainda que o STF já tenha desempenhado essa tarefa em algumas oportunidades, quando, ao declarar a inconstitucionalidade de determinada lei, de certa forma indicou que o caminho para a mudança pretendida deveria ser o da emenda constitucional, ${ }^{71}$ esse jogo de ação-reação, típico da ideia de diálogo, fica limitado, entre nós, não apenas pelos ônus político e deliberativo mencionados supra, mas também - e fortemente - pela previsão de imutabilidade de algumas disposições constitucionais (as "cláusulas pétreas").

\section{Perspectivas para o Brasil: aperfeiçoamento ou importação de um modelo}

É facilmente perceptível que, ao longo de boa parte deste texto, pretendi dar ênfase às ideias de deliberação e diálogo entre poderes. A razão para isso é simples, mas desvia-se do debate tradicional sobre controle de constitucionalidade no âmbito jurídico-constitucional. Estou convencido de que o aperfeiçoamento do controle de constitucionalidade brasileiro não passa pela importação desse ou daquele modelo, desse ou daquele tipo de ação judicial.

Quando se fala em perspectivas sobre um determinado tema e quando se pretende propor modificações em um determinado arranjo institucional, algumas posturas são possíveis. Uma delas, muito comum, é propor a importação completa de um modelo estrangeiro, o que, a não ser em casos excepcionais, não é factível. Isso por duas razões principais:

porque envolve uma mudança institucional radical que costuma exigir uma igualmente radical reforma da constituição;

porque costuma ignorar as peculiaridades da realidade do país receptor. Essa postura, que pode ser resumida no pensamento "existe um modelo pronto e,

\footnotetext{
${ }^{70}$ Essa metáfora foi utilizada por Favoreu para fazer referência a uma das tarefas do Conselho Constitucional francês. Segundo ele, o Conselho, "situado em um entroncamento crucial é, de certa forma, um guarda-chaves ou um regulador a indicar que via - regulamentar, legislativa ordinária, legislativa orgânica ou constitucional - a reforma deve seguir para ser adotada" (cf. Favoreu, 1982:419).

${ }_{71}$ Talvez os casos mais conhecidos sejam as decisões que declararam a inconstitucionalidade de leis que instituíam a progressividade do IPTU, o que fez com que o Congresso Nacional reagisse e alterasse a Constituição (EC no 29/2000).
} 
embora não haja perspectivas para a sua adoção, entendo que o Brasil deva adotá-1o" não será trilhada aqui. Propostas messiânicas não costumam gerar nenhum efeito.

A conclusão deste trabalho pretende ser um pouco mais realista, sem abandonar, contudo, as importantes conclusões a que se chegou ao longo da exposição. A primeira premissa dessa postura realista é a de que o momento para o pensamento institucional completamente inovador e ilimitado esgotou-se no dia 5 de outubro de 1988. Agora, temos de lidar com a Constituição que aí está e não ignorá-la.

Mas não é apenas com a nossa Constituição que devemos lidar, devemos lidar também com a nossa realidade. Nem os tribunais constitucionais europeus, nem os juízes norte-americanos deparam-se com os problemas que existem no Brasil. ${ }^{72}$ Por isso, querer apenas importar modelos prontos pode ser sinônimo de perder a oportunidade de aperfeiçoar o modelo brasileiro de controle de constitucionalidade a partir do que já temos. Isso não significa - ao contrário do que uma interpretação simplória do que foi afirmado poderia levar a crer - que devemos ignorar as experiências internacionais. Isso não apenas seria contraditório com todo o debate travado ao longo deste texto, mas também com a tendência internacional de migração de ideias e de empréstimos constitucionais. ${ }^{73}$

Dentro da moldura delimitada - levar em consideração a experiência estrangeira sem a pura e simples importação de modelos - parece-me possível propor algumas ideias conclusivas acerca do modelo brasileiro de controle de constitucionalidade.

A primeira delas diz respeito à ideia de "deliberação". Como exposto anteriormente, os ministros do Supremo Tribunal Federal não interagem entre si. Nesse ponto, é preciso tornar o STF uma instituição que tenha voz própria, que não seja a soma de 11 vozes dissociadas. Em sua forma atual, não há deliberação, não há busca de clareza ou de consenso, não existem concessões mútuas entre os ministros. Se um tribunal, no exercício do controle de constitucionalidade, tem que ser um locus privilegiado da deliberação e da razão pública, e se sua legitimidade depende da qualidade de sua decisão, é preciso repensar a forma de deliberação do STF. Além disso, parece-me claro que uma unidade institucional é pré-requisito para o diálogo, já que o diálogo constitucional não ocorre entre pessoas, mas entre instituições. Por fim, é possível afirmar que a própria vinculação das decisões do

\footnotetext{
72 Talvez o maior exemplo disso seja a jurisprudência nacional sobre direitos sociais, que não tem paralelo nem na Europa, nem nos Estados Unidos.

${ }^{73}$ A esse respeito, cf., por exemplo, os textos do simpósio "Constitutional Borrowing", publicados em International Journal of Constitutional Law (2003:177-324) e as contribuições apresentadas ao seminário "Migration of Constitutional Ideas", publicadas em Choudhry (2006).
} 
Supremo Tribunal Federal depende, em certa medida, dessa unidade institucional. ${ }^{74} \mathrm{E}$ para fomentar um aumento no grau de deliberação e de diálogo interno no Supremo Tribunal Federal, não são necessárias reformas constitucionais, bastam algumas reformulações no seu regimento interno. Essas simples reformulações regimentais teriam, talvez, o potencial de produzir transformações mais profundas e benéficas do que grandes pacotes constitucionais ou legislativos.

A segunda ideia diz respeito à tentativa de conciliação de posições extremas, como as de Dworkin e Waldron. Essa tentativa, que procura superar radicalizações como aquelas expressas por motes, como "todo o poder aos juízes" ou "todo o poder ao legislador", implica necessariamente a construção de um "diálogo entre poderes".

Essa possibilidade de diálogo parece-me factível e necessária, sobretudo em um dos âmbitos mais importantes do controle de constitucionalidade nos países em desenvolvimento: o controle de constitucionalidade por omissão, sobretudo no âmbito dos direitos sociais e das políticas públicas. ${ }^{75}$

Nesse âmbito costumam reinar as duas alternativas rejeitadas supra: ou se defende "todo poder aos juízes", o que costuma acarretar, para usar a expressão de José Reinaldo de Lima Lopes (1994:142), um "voluntarismo irracional” de juízes que procuram implementar políticas públicas sem conhecer as políticas existentes; ou se defende que os juízes não podem se intrometer na esfera do Poder Legislativo, por questões de separação de poderes. Ora, se se supera essa dualidade radical, e se se tem em mente que a decisão do Judiciário não é necessariamente a última palavra sobre o assunto, mas pura e simplesmente uma parte de um diálogo incessante, talvez seja possível conciliar ambas as posições.

Nesse ponto, de novo, é preciso ter em mente o alerta de Rawls (1993:232): o poder final não pode ser deixado para o Poder Legislativo, mas também não para o Poder Judiciário. O poder final é "compartilhado" pelos três poderes em conjunto, em uma relação harmoniosa entre si, e todos eles são responsáveis perante a sociedade civil. Para tanto, é preciso haver diálogo. ${ }^{76}$

\footnotetext{
74 Pelo menos se por "vinculação" se entender não apenas a vinculação de um placar, mas também de uma ratio decidendi.

${ }^{75}$ Cf., em sentido semelhante, Dixon, 2007:391-418 e Tushnet, 2008:227 e segs. A menção a ambos os autores, nesse ponto, não implica, contudo, uma concordância com todas as suas ideias acerca do controle de constitucionalidade no âmbito dos direitos sociais.

${ }^{76}$ Uma possibilidade já existente de diálogo no Brasil é aquela que pode ocorrer no momento final do controle difuso. Após a decisão definitiva do Supremo Tribunal Federal, ainda vinculada a um determinado caso concreto, compete ao Senado Federal, nos termos do art. 52, X, da Constituição, suspender a execução, com efeitos para todos, da lei declarada inconstitucional pelo STF. Inúmeros autores sustentam que o Senado Federal não é obrigado a realizar essa suspensão da lei (cf., nesse sentido, Brossard, 1976:64; Clève, 2000:121-122; e Mendes, 1990:216). Nesse sentido, ainda que de forma extremamente limitada e com efeitos pouco amplos, haveria uma espécie de "legislative override" no controle de constitucionalidade brasileiro. Entre a sustentação oral deste texto e a sua publicação, entrou na pauta
} 
Mais uma vez, não se exige uma importação de modelos ou de ações para que a mudança desejada possa ser atingida. Exigível é apenas uma lenta mudança de concepção acerca do controle de constitucionalidade. A principal mudança de concepção é a superação da mencionada "visão guilhotina", segundo a qual o controle judicial de constitucionalidade é simplesmente um conjunto de ações (no sentido do direito processual) que conduz a lei para a guilhotina anuladora do Judiciário. Essa visão, extremamente enraizada no âmbito jurídico, é por demais redutora para dar conta do fenômeno "controle de constitucionalidade", como se procurou demonstrar ao longo deste trabalho.

Em suma: o necessário é encarar o controle de constitucionalidade como algo que "não é mero processo". Isso significa que, enquanto a discussão continuar a ser um debate sobre a criação de novas ações judiciais, o debate não progredirá. Controle de constitucionalidade é "parte do jogo democrático", é algo muito mais complexo do que mero procedimento judicial. Nesse sentido, se faz preciso - e urgente - iniciar uma discussão sobre a forma de decidir do Supremo Tribunal Federal, sobre formas de incrementar a interação entre os ministros e as possibilidades de diálogo. Nesse ponto, a ideia de deliberação interna pode ser uma ótima ideia-guia.

\section{Referências}

ACKERMAN, Bruce A. We the people: 1. Foundations. Cambridge, Mass.: Belknap Press, 1991.

AVRIL, Pierre; GICQUEL, Jean. Le conseil constitutionnel. 5. ed. Paris: Montchrestien, 2005.

BAMFORTH, Nicholas. Parliamentary sovereignty and the Human Rights Act 1998, Public Law, p. 572-582, 1998.

BARBOSA, Rui. Estado de sítio. Rio de Janeiro: Cia. Impressora, 1892. . Comentários à Constituição Federal brasileira. São Paulo: Saraiva, 1933. v. IV. . A Constituição e os atos inconstitucionais. Rio de Janeiro: Atlântida. s.d.

de julgamentos do STF a Reclamação no 4.335 , cujo objeto, a partir do voto do ministro relator Gilmar Mendes, passou a envolver a definição do papel do Senado Federal no controle difuso de constitucionalidade no Brasil. Se confirmada a tese defendida pelo relator, a consequência será tornar supérfluo o papel do Senado Federal no momento final desse controle difuso. 
BARROSO, Luís Roberto. O controle de constitucionalidade no direito brasileiro. 2. ed. São Paulo: Saraiva, 2006.

BARTHÉLEMY, Joseph; DUEZ, Paul. Traité élémentaire de droit constitutionnel. Paris: Dalloz, 1926.

BASTID, Paul. Sieyès et sa pensée. Paris: Hachette, 1939.

BAUM, Lawrence. Judges and their audiences: a perspective on judicial behavior. Princeton: Princeton University Press, 2006.

BAYON, Juan Carlos. Derechos, democracia y Constitución. In: CARBONELL, Miguel (Org.). Neoconstitucionalismo(s). Madrid: Trotta, 2003.

BITTENCOURT, C. A. Lúcio. O controle jurisdicional da constitucionalidade das leis. 2. ed. Rio de Janeiro: Forense, 1968.

BONGIOVANNI, Giorgio. Rechtsstaat and constitutional justice in Austria: Hans Kelsen's contribution. In: COSTA, Pietro; ZOLO, Danilo (Org.). The rule of law: history, theory and criticism. Dordrecht: Springer, 2007.

BROSSARD, Paulo. O Senado e as leis inconstitucionais. Revista de Informação Legislativa, n. 50, p. 55-64, 1976.

BURDEAU, Georges. Traité de science politique. 2. ed. Paris: LGDJ, 1969. v. IV.

BUTLER, Andrew S. The bill of rights debate: why the New Zealand Bill of Rights Act 1990 is a bad model for Britain. Oxford Journal of Legal Studies, n. 17, p. 325-345, 1997.

CANOTILHO, J. J. Gomes. Direito constitucional e teoria da Constituição. 2. ed. Coimbra: Almedina, 1998.

CHOUDHRY, Sujit. The migration of constitutional ideas. Cambridge, Mass.: Cambridge University Press, 2006.

CLÈVE, Clèmerson Merlin. A fiscalização abstrata de constitucionalidade no direito brasileiro. 2. ed. São Paulo: Revista dos Tribunais, 2000.

COHEN, Joshua. Deliberation and democratic legitimacy. In: HAMLIN, Alan; PETTIT, Philip (Orgs.). The good polity: normative analysis of the State. Oxford: Blackwell, 1989.

CONSTANT, Benjamin. De l'esprit de conquête et de l'usurpation. In: CONSTANT, Benjamin. Écrits politiques. Paris: Gallimard, 1997a.

. De la liberté des anciens comparée à celle des modernes (discours prononcé à l'Athénée Royal de Paris en 1819). In: CONSTANT, Benjamin. Écrits politiques. Paris: Gallimard, 1997b. 
CRAIG, Paul. Constitutional and non-constitutional review. Current Legal Problems, n. 54, p. 147-178, 2001.

DIXON, Rosalind. Creating dialogue about socioeconomic rights. International Journal of Constitutional Law, n. 5, p. 391-418, 2007.

DWORKIN, Ronald. Freedom's law: the moral reading of the American Constitution. Oxford: Oxford University Press, 1996.

Is there a right to pornography?. Oxford Journal of Legal Studies, n. 1, p. 177-212, 1981.

. A matter of principle. Cambridge, Mass.: Harvard University Press, 1985.

EISENMANN, Charles. La justice constitutionnelle et la Haute Cour Constitutionnelle d'Autriche. Paris: LGDJ, 1928.

ELSTER, Jon (Org.). Deliberative democracy. Cambridge, Mass.: Cambridge University Press, 1998.

ELY, John Hart. Democracy and distrust: a theory of judicial review. Cambridge, Mass.: Harvard University Press, 1980.

FAVOREU, Louis. Les décisions du Conseil constitutionnel dans l'affaire des nationalisations. Revue du Droit Public, n. 98, p. 377-420, 1982.

. La politique saisie par le droit. Paris: Economica, 1988.

FEREJOHN, John; PASQUALE, Pasquino. Constitutional courts as deliberative institutions: towards and institutional theory of constitutional justice. In: SADURSKI, Wojciech (Org.). Constitutional justice, east and west: democratic legitimacy and constitutional courts in post-communist Europe in a comparative perspective. Den Haag: Kluwer, 2002.

Constitutional adjudication: lessons from Europe. Texas Law Review, n. 82, p. 1671-1704, 2004.

FERREIRA FILHO, Manoel Gonçalves. Curso de direito constitucional. 32. ed. São Paulo: Saraiva, 2006.

FISHER, Louis. Constitutional dialogues: interpretation as political process. Princeton: Princeton University Press, 1988.

GARDBAUM, Stephen. The new commonwealth model of constitutionalism. American Journal of Comparative Law, n. 49, p. 707-760, 2001.

GOLDSWORTHY, Jeffrey. Legislative sovereignty and the rule of law. In: CAMPBELL, Tom; EWING, K. D.; TOMKINS, Adam (Orgs.). Sceptical essays on human rights. Oxford: Oxford University Press, 2002. 
. Judicial review, legislative override, and democracy. In: CAMPBELL, Tom; GOLDSWORTHY, Jeffrey; STONE, Adrienne (Orgs.). Protecting human rights: instruments and institutions. Oxford: Oxford University Press, 2003.

GUTMANN, Amy; THOMPSON, Dennis Frank. Why deliberative democracy? Princeton: Princeton University Press, 2004.

HABERMAS, Jürgen. Strukturwandel der Öffentlichkeit. Frankfurt: Suhrkamp, 1962.

. Faktizität und Geltung: Beiträge zur Diskurstheorie des Rechts und des demokratischen Rechtsstaats. Frankfurt am Main: Suhrkamp, 1992.

. Human rights and popular sovereignty: the liberal and Republican versions. Ratio Juris, n. 7, p. 1-13, 1994.

HAMILTON, Alexander; MADISON, James; JAY, John. The federalist. [1787-88] Chicago: Britannica (Great Books of the Western World), 1952.

HICKMAN, Tom R. Constitutional dialogue, constitutional theories and the Human Rights Act 1998. Public Law, p. 306-335, Summer 2005.

HOGG, Peter W.; BUSHELL, Allison A. The charter dialogue between courts and legislatures (or perhaps the charter of rights isn't such a bad thing after all). Osgoode Hall Law Journal, n. 35, p. 75-124, 1997.

JELLINEK, Georg. Ein Verfassungsgerichtshof für Österreich. Wien: Hölder, 1885.

. Allgemeine Staatslehre. 3. ed., Berlin: Häring, 1914.

JESTAEDT, Matthias. Der "Hüter der Verfassung" als Frage des Rechtsgewinnungsverständnisses: ein etwas anderer Blick auf die Schriften von Carl Schmitt und Hans Kelsen. In: BEAUD, Olivier; PASQUINO, Pasquale (Orgs.). La controverse sur «le gardien de la constitution» et la justice constitutionnelle: Kelsen contre Schmitt. Paris: LGDJ, 2007.

KAHANA, Tsvi. The notwithstanding mechanism and public discussion: lessons from the ignored practice of section 33 of the charter. Canadian Public Administration, n. 44, p. 255-291, 2001.

KELSEN, Hans. La garantie juridictionnelle de la Constitution (la justice constitutionnelle). Revue du Droit Public et de la Science Politique en France et à l'Etranger, $\mathrm{n}$. 35, p. 197-257, 1928.

. Wesen und Entwicklung der Staatsgerichtsbarkeit. Veröffentlichungen der Vereinigung der Deutschen Staatsrechtslehrer, n. 5, p. 31-88, 1929.

. Wer soll der Hüter der Verfassung sein? Die Justiz, n. 11-12, p. 576-628, 1930/31. 
. General theory of law and State. Cambridge, Mass.: Harvard University Press, 1949.

. Reine Rechtslehre. 2. ed. Wien: Deuticke, 1960.

LASSER, Mitchel de S.-O.-L'E. Judicial deliberations: a comparative analysis of judicial transparency and legitimacy. Oxford: Oxford University Press, 2004.

LEBECK, Carl. Weak forms of judicial review: a solution for the "mighty problem"? Zeitschrift für öffentliches Recht, n. 60, p. 55-110, 2005.

LESSA, Pedro. Do Poder Judiciário. Rio de Janeiro: Francisco Alves, 1915.

LOPES, José Reinaldo de Lima. Direito subjetivo e direitos sociais. In: FARIA, José Eduardo (Org.). Direitos humanos, direitos sociais e justiça. São Paulo: Malheiros, 1994.

MELLO, Oswaldo Aranha Bandeira. A teoria das constituições rígidas. São Paulo: Revista dos Tribunais, 1934.

MENDES, Conrado Hübner. Controle de constitucionalidade e democracia. Rio de Janeiro: Elsevier, 2008.

MENDES, Gilmar Ferreira. Controle de constitucionalidade. São Paulo: Saraiva, 1990.

MIRANDA, Francisco Cavalcanti Pontes de. Fundamentos actuaes do direito constitucional. Rio de Janeiro: Freitas Bastos, 1932.

. Defesa, guarda e rigidez das constituições. Revista de Direito Administrativo, n. 4, p. 1-12, 1946.

MIRANDA, Jorge. Manual de direito constitucional. [1981]. Coimbra: Coimbra Editora, 1983. v. II.

NINO, Carlos Santiago. The Constitution of deliberative democracy. New Haven: Yale University Press, 1996.

NOLL, Alfred J. Georg Jellineks Forderung nach einem Verfassungsgerichtshof für Österreich. In: PAULSON, Stanley L.; SCHULTE, Martin (Orgs.). Georg Jellinek: Beiträge zu Leben und Werk. Mohr, 2000.

NUNES, José de Castro. Teoria e prática do Poder Judiciário. Rio de Janeiro: Forense, 1943.

PASQUINO, Pasquale. Gardien de la Constitution ou justice constitutionnelle? Carl Schmitt et Hans Kelsen. In: TROPER, Michel; JAUME, Lucien (Orgs.). 1789 et l'invention de la Constitution. Paris: LGDJ, 1994. 
PAULSON, Stanley L. On Hans Kelsen's role in the formation of the Austrian Constitution and his defense of constitutional review. In: KRAWIETZ, Werner; SUMMERS, Robert S.; WEINBERGER, Ota; VON WRIGHT, Georg Henrik (Orgs.). The reasonable as rational? On legal argumentation and justification - Festschrift for Aulis Aarnio. Berlin: Duncker \& Humblot, 2001.

RAWLS, John. Political liberalism. New York: Columbia University Press, 1993.

. The idea of public reason revisited. University of Chicago Law Review, n. 64, p. 765-807, 1997.

$\mathrm{ROACH}$, Kent. Constitutional and common law dialogues between the Supreme Court and canadian legislatures. The Canadian Bar Review, n. 80, p. 481-533, 2001.

. Dialogic judicial review and its critics. Supreme Court Law Review, n. 23, p. 49-104, 2004.

. Dialogue or defiance: legislative reversals of Supreme Court decisions in Canada and the United States. International Journal of Constitutional Law, n. 4, p. 347-370, 2006.

ROUSSEAU, Dominique. Droitdu contentieux constitutionnel.5.ed. Paris: Montchrestien, 1999.

SAMPAIO, Marco Aurélio. A medida provisória no presidencialismo brasileiro. São Paulo: Malheiros, 2007.

SCHMITT, Carl. Der Hüter der Verfassung. Archiv des Öffentlichen Rechts, n. 16, p. 161-237, 1929.

. Der Hüter der Verfassung. [1931]. 3. ed. Berlin: Duncker \& Humblot, 1985.

. Das Reichsgericht als Hüter der Verfassung. In: SCHMITT, Carl. Verfassungsrechtliche Aufsätze aus den Jahren 1924-1954. [1958]. 3. ed. Berlin: Duncker \& Humblot, 1985.

. Verfassungslehre. [1928]. 8. ed. Berlin: Duncker \& Humblot, 1993.

SILVA, José Afonso da. Curso de direito constitucional positivo. 27. ed. São Paulo: Malheiros, 2006.

SILVA, Virgílio Afonso da. Interpretação conforme a Constituição: entre a trivialidade e a centralização judicial. Revista Direito GV, n. 3, p. 191-210, 2006.

- Direitos fundamentais: conteúdo essencial, restrições e eficácia. São Paulo: Malheiros, 2009.

SINNOTT-ARMSTRONG, Walter. Weak and strong judicial review. Law and Philosophy, n. 22, p. 381-392, 2003. 
STONE, Alec. The birth of judicial politics in France. Oxford: Oxford University Press, 1992.

SIEYÈS, Emmanuel Joseph. Essai sur les privilèges et autres textes. Paris: Dalloz, 2007.

TRIBE, Laurence. The puzzling persistence of process-based constitutional theories. Yale Law Journal, n. 89, p. 1063-1080, 1980.

TROPER, Michel. The Logic of justification of judicial review. International Journal of Constitutional Law, n. 1, p. 99-121, 2003.

TUSHNET, Mark. Alternative forms of judicial review. Michigan Law Review, n. 101, p. 2781-2802,2003a.

. New forms of judicial review and the persistence of rights - and democracy - based worries. Wake Forest Law Review, n. 38, p. 813-838, 2003 b.

. Weak courts, strong rights: judicial review and social welfare rights in comparative constitutional law. Princeton: Princeton University Press, 2008.

VEDEL, Georges. Neuf ans au Conseil constitutionnel. Le Débat, n. 55, p. 48-56, 1989.

WALDRON, Jeremy. A right-based critique of constitutional rights. Oxford Journal of Legal Studies, v. 13, n. 1, p. 18-51, 1993.

. Law and disagreement. Oxford: Clarendon Press, 1999.

WEBBER, Jeremy. Institutional dialogue between courts and legislatures in the definition of fundamental rights: lessons from Canada (and elsewhere). In: SADURSKI, Wojciech (Org.). Constitutional justice, east and west: democratic legitimacy and constitutional courts in post-communist Europe in a comparative perspective. Den Hagen: Kluwer, 2002.

ZAGREBELSKY, Gustavo. La giustizia costituzionale. Bologna: Il Mulino, 1977. 